\title{
TATA KELOLA TEKNOLOGI INFORMASI PADA SEKTOR PUBLIK: PENYELARASAN TEKNOLOGI INFORMASI DENGAN VISI KEPEMIMPINAN (STUDI KASUS: KOTA SALATIGA DAN KABUPATEN BENGKAYANG)
}

\author{
Andeka Rocky Tanaamah', Agustinus Fritz Wijaya*2, Sarah Ayu Maylinda ${ }^{3}$ \\ 1,2,3 Universitas Kristen Satya Wacana, Salatiga \\ Email: 1atanaamah@uksw.edu, ${ }^{2}$ agustinus.wijaya@uksw.edu*,3682017043@student.uksw.edu \\ *Penulis Korespondensi
}

(Naskah masuk: 01 Agustus 2021, diterima untuk diterbitkan: 17 November 2021)

\begin{abstract}
Abstrak
Tata kelola Teknologi Informasi (TI) dibutuhkan di suatu organisasi pada saat ini menjadi perhatian utama dalam mengembangkan layanan yang telah berbasis TI. Adanya kebutuhan untuk menghasilkan kualitas layanan TI yang kredibel dan transparan telah mendorong setiap organisasi baik sektor swasta maupun sektor publik. Beberapa penelitian menunjukkan bahwa 75\% adopsi suatu teknologi sering berujung kegagalan. Persoalan utama yang menyebabkan kegagalan implementasi Information Technology Governance (ITG) terletak pada operasional TI. Penelitian ini bertujuan untuk: 1) mengidentifikasi faktor-faktor kepemimpinan yang menitikberatkan kepada TI berpengaruh dalam keberhasilan maupun kegagalan implementasi tata kelola TI; (2) Sejauh mana mana visi kepemimpinan dapat mendorong implementasi ITG pada Sektor Publik. Metode kualitatif digunakan untuk memecahkan masalah tersebut, lokasi penelitian ini berada di Kota Salatiga dan Kabupaten Bengkayang. Dalam penelitian ini ditemukan faktor-faktor yang berperan seperti: komitmen kepala daerah, kemampuan dalam menjabarkan visi dan misi, ketersediaan regulasi dan aturan, dukungan untuk mengimplementasikan TI, kemampuan dalam konsolidasi dan pengelolaan, penataan kelembagaan, dukungan dan alokasi anggaran, ketersediaan infrastruktur, sumber daya manusia, dan kemampuan dalam mengembangkan strategi implementasi. Oleh karena faktor tersebut, dukungan visi kepemimpinan dalam mengembangkan tata kelola pemerintahan dapat menjadi basis reformasi birokrasi.
\end{abstract}

Kata kunci: Tata Kelola Teknologi Informasi, Sektor Publik, Kepemimpinan, Salatiga, Bengkayang.

\section{INFORMATION TECHNOLOGY GOVERNANCE IN THE PUBLIC SECTOR: INFORMATION TECHNOLOGY ALIGNMENT WITH LEADERSHIP VISION (CASE STUDY: SALATIGA CITY AND BENGKAYANG REGENCY)}

\begin{abstract}
Information Technology (IT) governance is required in an organization is currently a major concern in developing IT-based services. The need to produce quality IT services that are credible and transparent has encouraged every organization, both private and public sectors. Several studies show that $75 \%$ of the adoption of technology often leads to failure. The main problem that causes the failure of the implementation of Information Technology Governance (ITG) lies in IT operations. This study aims to: 1) identify leadership factors that focus on IT that influence the success or failure of IT governance implementation; (2) The extent to which the leadership vision can encourage the implementation of ITG in the Public Sector. Qualitative methods are used to solve the problem, the location of this research is in Salatiga City and Bengkayang Regency. This study found factors that play a role such as the commitment of the regional head, the ability to describe the vision and mission, the availability of regulations and rules, support for implementing IT, the ability to consolidate and manage, institutional structuring, support, and budget allocation, availability of infrastructure, resources human resources, and the ability to develop implementation strategies. Because of these factors, the support for the vision of leadership in developing good governance can be the basis for bureaucratic reform.
\end{abstract}

Keywords: Information Technology Governance, Public Sector, Leadership, Salatiga, Bengkayang.

\section{PENDAHULUAN}

Tata kelola Teknologi Informasi (TI) pada saat ini menjadi perhatian utama dalam mengembangkan layanan berbasis TI. Adanya kebutuhan untuk menghasilkan kualitas layanan TI yang kredibel dan transparan telah mendorong setiap organisasi baik 
sektor swasta maupun sektor publik. Keberhasilan adopsi teknologi dipengaruhi oleh kinerja organisasi (Ren, 2019). Persoalan utama yang menyebabkan kegagalan implementasi Information Technology Governance (ITG) terletak pada operasional TI (Benaroch \& Chernobai, 2017). Mengacu pada pemahaman tersebut, maka terlihat pada sejauh mana visi dan tujuan tersebut dapat diterjemahkan dalam operasional dan tata kelola di setiap unit atau departemen yang ada. Apalagi jika dipandang bahwa investasi implementasi TI bukanlah merupakan biaya murah. Oleh karena itu dibutuhkan pengelolaan investasi TI yang baik. ITG pada sektor publik merupakan layanan pemerintah untuk melayani masyarakat (Laita \& Belaissaoui, 2017). Sektor publik dibedakan sebagai organisasi pemerintah yang berorientasi pada publik, sedangkan sektor swasta atau privat merupakan organisasi yang berorientasi pada profit (Alford \& Greve, 2017). Tata kelola TI pada sektor swasta digunakan untuk menjalankan kegiatan operasional, sedangkan pada sektor publik masih terbatas sebagai perangkat pendukung manajemen organisasi (Belhaj \& Zahi, 2019).

Penerapan IT governance di Indonesia bukanlah merupakan hal yang baru. Kebutuhan dalam menerapkan TI pada sebagai aspek pelaksanaan di organisasi pemerintahan telah menjadi perhatian utama dalam setiap unsur yang ada di setiap pemerintah daerah. Hal ini terlihat dalam beberapa produk perundang-undangan seperti UUD 1945 pasal $28 \mathrm{~F}$ tentang hak untuk berkomunikasi dan memperoleh informasi, Instruksi Presiden Nomor 3 Tahun 2003 tentang kebijakan dan strategi pengembangan E-Government, Undang-Undang Republik Indonesia Nomor 22 tahun 1999 tentang Pemerintahan Daerah, Undang-Undang Republik Indonesia Nomor 25 tahun 1999 tentang Perimbangan Keuangan antara Pemerintah Pusat dan Daerah, Undang-Undang Republik Indonesia Nomor 36 tahun 1999 tentang Telekomunikasi, Peraturan Presiden (Perpres) Nomor 95 Tahun 2018 tentang Sistem Pemerintahan Berbasis Elektronik (SPBE), Peraturan Menteri Pendayagunaan Aparatur Negara dan Reformasi Birokrasi Republik Indonesia nomor 5 Tahun 2018 Tentang Pedoman Evaluasi Sistem Pemerintahan Berbasis Elektronik, Buku Panduan Penyusunan Master Plan Smart City 2017.

Namun, adanya peraturan maupun perundangundangan tidaklah menyebabkan persoalan dianggap selesai, dibutuhkan aktor yang dapat mengimplementasikan dan dapat menjalankan semua ini. Salah satu faktor penting yang perlu diperhatikan dalam implementasi tata kelola TI adalah faktor kepemimpinan. Kepemimpinan yang dimaksudkan yaitu adanya visi pemimpin yang dapat mendorong proses penyelarasan antara apa yang diinginkan dengan implementasi ITG dalam sistem organisasi secara keseluruhan. Penyelarasan visi kepemimpinan dalam implementasi tercermin melalui adanya tujuan, perencanaan dan implementasi TI dalam setiap aktivitas organisasi. Hal ini sering menjadi masalah yang sering dihadapi sehingga berdampak pada adanya kegagalan implementasi ITG itu sendiri.

Kajian mengenai ITG telah banyak dilakukan oleh para peneliti, sejauh ini penelitian-penelitian tersebut berorientasi pada penerapan tata kelola TI dan evaluasi tentang keberhasilan maupun kegagalan yang diletakkan pada kerangka kesesuaian antara perencanaan dengan kemanfaatan yang tertuju pada implementasi tata kelola TI. Berdasarkan kajian literatur yang dilakukan, maka masih minim mengenai kajian yang lebih berorientasi pada kepemimpinan TI. Keberhasilan implementasi dan pelaksanaan TI sangat tergantung pada para pemimpin yang memiliki visi menyelaraskan antara kebutuhan pemanfaatan TI dengan visi kepemimpinan pemimpin di pemerintahan daerah. Pada beberapa kasus, implementasi tata kelola TI dapat berjalan dengan baik, yang disebabkan karena adanya visi kepemimpinan TI yang kuat pada pemimpin tersebut. Tanpa adanya visi kepemimpinan maka berdampak pada rendahnya implementasi dan pemanfaatan ITG.

Studi ini dilakukan di Kabupaten Bengkayang (Provinsi Kalimantan Barat) dan Kota Salatiga (provinsi Jawa Tengah). Mengacu pada pemahaman di atas, maka tujuan penelitian ini adalah: 1) mengidentifikasi faktor-faktor kepemimpinan TI berpengaruh dalam keberhasilan maupun kegagalan implementasi tata kelola TI; (2) Sejauh mana mana visi kepemimpinan dapat mendorong implementasi ITG pada sektor publik.

Kepemimpinan tidak dapat dipisahkan dalam mendorong implementasi ITG dalam organisasi baik private sector maupun public sector. Berbagai penelitian dilakukan untuk mendukung implementasi tata kelola TI pada sektor publik. Thite misalnya, yang melihat tidak ada satu gaya kepemimpinan pada semua proyek teknologi informasi. Kesuksesan kepemimpinan TI dipengaruhi oleh gaya kepemimpinan organisasi itu sendiri (El-Ebiary et al., 2020). Model kepemimpinan TI dipandang sebagai kemampuan CIO dalam mengartikulasikan visi pada teknologi informasi dalam organisasi serta bagaimana model ITG yang tepat guna memastikan bahwa visi tersebut dapat dipahami oleh manajer organisasi (Wu et al., 2015), (Wiedenhoft et al., 2017). Kepemimpinan TI merupakan salah satu faktor kunci kesuksesan dalam mengembangkan keberhasilan tata kelola TI yang efektif (Alreemy et al., 2016). Dalam mengembangkan ITG maka salah satu faktor penting bagi para pemimpin adalah adanya transfer pengetahuan untuk mengembangkan organisasi. Pemimpin yang efektif dapat mengimplementasikan perubahan, membangun kapabilitas organisasinya, dan meningkatkan kinerjanya (Amiry et al., 2020). Nilai investasi TI yang dilakukan dapat dikatakan berhasil, sesuai dengan kebutuhan ITG sejalan dengan model yang dikembangkan oleh Weil \& Ross yang menegaskan 
bahwa tata kelola TI yang efektif merupakan kebutuhan penting dalam menilai keberhasilan keseluruhan organisasi dari TI (Budirahardjo, 2017).

Mengacu pada paparan di atas, maka kepemimpinan merupakan faktor penting dalam mendorong implementasi ITG dalam sektor publik. Kepemimpinan TI merupakan salah satu faktor kunci keberhasilan dalam penerapan TI di organisasi (Laureani \& Antony, 2016). Pada sektor publik dibutuhkan relasi yang kuat antara para pemimpin yang lebih mengendalikan tentang strategi dan pelaksana setiap unsur dalam organisasi. Hal ini ditegaskan oleh Ali \& Green menemukan terdapat relasi yang positif dan kuat antara keberadaan komite strategi dan organisasi pada keseluruhan tingkat efektifitas ITG pada organisasi sektor publik di Australia. Relasi tersebut menemukan bahwa implementasi IT governance pada sektor pemerintah membutuhkan perbaikan pada struktur, proses, dan mekanisme relasional untuk mendukung akuntabilitas proyek TI dan kontribusinya pada efektivitas implementasi dalam organisasi. Oleh karena itu, kombinasi antara proses, struktur, dan mekanisme relasional merupakan faktor penting dalam mengembangkan ITG pada sektor publik

Relasi yang baik akan terbangun apabila dipadukan dengan adanya unsur kepemimpinan IT yang kuat, yang dapat membawa perbaikan pada setiap unsur maupun proses yang ada. IT governance merupakan kesatuan dari kepemimpinan, struktur organisasi, dan proses yang memastikan organisasi TI dapat bertahan dan memperluas strategi dan tujuan organisasi. Dilihat dari sisi tata kelola struktur, maka akan membawa keuntungan bagi perusahaan, sedangkan dari sisi proses dan mekanisme relasi membawa dampak negatif bagi perusahaan (Chong \& Duong, 2017).

Nfuka \& Rusu menyatakan bahwa faktor yang memiliki korelasi signifikan terhadap kinerja tata kelola TI adalah dukungan senior manajemen guna mengkonsolidasi, standarisasi, maupun mengelola infrastruktur TI dan aplikasi sistem informasi guna mengoptimasi biaya dan aliran informasi pada organisasi publik. Para pembuat keputusan perlu melakukan perencanaan optimal dan menggunakan sumber daya TI yang memiliki dampak besar dalam peningkatan pelayanan publik.

Tata kelola TI dibutuhkan guna memastikan agar investasi TI berjalan baik dan menghindarkan dari resiko kegagalan proyek TI guna mencapai tujuan organisasi. Perhatian terhadap tata kelola TI perlu diberikan perhatian yang besar. Rendahnya perhatian terhadap ITG pada sektor publik berdampak pada ketersediaan anggaran yang tidak mencukupi. Penerapan ITG pada sektor publik masih belum banyak ditemui dan tergolong baru (Jonatan \& Rusu, 2018). Dalam mengimplementasikan ITG pada sektor publik dibutuhkan fleksibilitas dan tidak kaku, serta dibutuhkan pengaturan tanggung jawab dan prosedur yang tidak kaku, serta ada penghargaan terhadap pencapaian yang dilakukan. Hasil penelitian menunjukkan bahwa pada sektor publik terdapat permasalahan anggaran dan pengambilan keputusan, disamping itu persoalan lainnya yang juga dihadapi berkenaan dengan rendahnya pengetahuan tentang ITG pada organisasi pemerintah.

Kinerja organisasi mempengaruhi keberhasilan implementasi TI. Selain itu, persoalan alokasi modal untuk pengembangan TI yang minim serta rencana strategis organisasi mempengarhui bagaimana keselarasan TI dan bisnis di dalam organisasi (Panda, 2021). Kepemimpinan TI juga dapat berdampak negatif pada kinerja perusahaan maupun organisasi yang disebabkan oleh karena komunikasi, kebijakan, dan kinerja keuangan.

\section{METODE PENELITIAN}

Penelitian ini berfokus pada visi kepemimpinan TI yang diterapkan atau diemban oleh para pemangku kepentingan dalam menyelaraskan antara kepentingan kepemimpinan dan implementasi ITG. Kegagalan implementasi TI disebabkan karena tidak adanya keselarasan antara visi kepemimpinan dalam bidang TI dengan tujuan dan strategi organisasi (Nor et al., 2021), (Larsen et al., 2021). Selain itu, faktor dukungan manajemen maupun alokasi anggaran belum berpihak pada implementasi dan pengembangan TI.

Mengacu pada pemahaman di atas, maka pendekatan yang digunakan dalam penelitian ini adalah pendekatan kualitatif. Hasil penelitian yang dilakukan diperoleh gambaran yang mendalam mengenai realitas visi kepemimpinan TI dalam perencanaan, implementasi, serta mengembangkan TI pada sektor pemerintahan (publik). Penelitian kualitatif pada dasarnya merupakan penelitian yang bersifat lintas disiplin, sehingga dalam membangun konsepsi, maka didasarkan pada pengalaman manusia (Gilbert, 2018). Berdasarkan pemahaman tersebut, maka dalam penelitian ingin menggali pengalamanpengalaman para pemimpin dalam membangun visi TI yang menjadi proses pembelajaran yang penting dalam membangun sudut pandang terhadap tata kelola TI.

Penelitian berfokus kepada faktor kepemimpinan TI pada sektor publik berdasarkan prinsip-prinsip tata kelola TI [(Ali \& Nisar, 2016) dan hubungannya dengan keselarasan strategi organisasi (Ilmudeen, 2021). Hal ini penting dilakukan agar diperoleh gambaran yang menyeluruh mengenai pengalaman-pengalaman para pemimpin dalam membangun tata kelola TI sebagai basis implementasi TI. Selain itu, penelitian kualitatif juga dipakai sebagai sarana untuk menjelaskan pemahaman mengenai cara, strategi, serta dapat menjelaskan berbagai faktor yang dapat membangun keberhasilan maupun kegagalan implementasi TI (Miles \& Huberman, 2014).

Penelitian ini dilakukan dalam rentang waktu empat bulan mulai bulan Desember 2020 sampai 
dengan bulan Maret 2021. Kota Salatiga dipilih sebagai objek penelitian, mengingat dari sisi usia, Salatiga didirikan pada tanggal 24 Juli tahun 750, dan saat ini telah berusia 1270 tahun. Mengacu pada usia tersebut, maka dipandang Salatiga merupakan kota yang sangat matang dan siap dalam implementasi $E$ Government sebagai basis layanan pada masyarakat. Kabupaten Bengkayang didirikan pada tanggal 27 April 1999, dan pada saat ini sudah berusia 21 tahun. Kabupaten Bengkayang dipilih karena posisinya yang berada di wilayah berbatasan antara Indonesia dan Malaysia. Posisi sebagai daerah perbatasan tentunya dibutuhkan komitmen yang tinggi dalam menjalankan dan mengimplementasikan layanan berbasis teknologi informasi. Narasumber yang dipergunakan dalam penelitian ini dari Kota Salatiga: 1) Yulianto yang merupakan Walikota Salatiga; 2) Prasetiyo Ichhiarto, Selaku Kepala Dinas Komunikasi dan Informatika; 3) Agung Hendratmiko selaku Kepala Bappeda; 4) Joko Wahono Selaku Kepala Bagian Pemerintahan Sekretariat Daerah. Dari sisi Pemerintah Kabupaten Bengkayang diwakili oleh: 1) Obaja, selaku Sekretaris Daerah merangkap Plh. Bupati Kabupaten Bengkayang dan Aleksius Kepala Dinas Komunikasi dan Informatika Kabupaten Bengkayang.

Guna mendukung penelitian dapat berjalan dengan baik, maka tahapan dalam penelitian ini dapat dilihat pada Gambar 1.

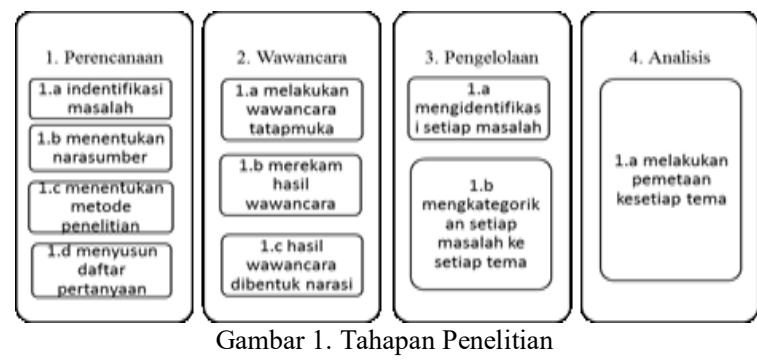

Mengacu pada Gambar 1, tahapan penelitian ini yaitu: melakukan identifikasi masalah berkenaan dengan (1) mengidentifikasi faktor-faktor kepemimpinan TI berpengaruh dalam keberhasilan maupun kegagalan implementasi tata kelola TI; (2) Sejauh mana mana visi kepemimpinan dapat mendorong implementasi ITG pada Sektor Publik. Guna menjawab masalah yang ada, maka langkah selanjutnya yang dilakukan adalah menentukan narasumber yang dipandang kompeten serta menentukan metodologi penelitian dan menyusun daftar pertanyaan.

Tahapan berikutnya adalah menggali informasi dari narasumber serta menarasikan hasil wawancara tersebut, yang kemudian dilanjutkan dengan tahapan pengelolaan. Tahapan ini peneliti melakukan identifikasi setiap masalah yang terjabar dalam hasil wawancara serta melakukan kategorisasi masalah dalam tema-tema yang dibangun. Tahap akhir dari penelitian ini yaitu tahapan analisis dengan melakukan pemetaan tema-tema penelitian. Hasil akhir dari penelitian ini adalah diperoleh informasi mengenai faktor dan masalah yang berkenaan dengan kepemimpinan TI.

\section{HASIL DAN PEMBAHASAN}

Penyelarasan tata kelola teknologi informasi dalam visi kepemimpinan pada sektor publik merupakan hal yang menarik untuk dikaji lebih dalam. Pemerintah Indonesia telah berkomitmen untuk menjadikan Teknologi Informasi sebagai bagian utama dalam pengelolaan sistem pemerintahannya, yang diawali dengan Instruksi Presiden Nomor 3 Tahun 2003 tentang Kebijakan dan Strategi Nasional Pengembangan E-Government yang bertujuan untuk menjamin keterpaduan sistem pengelolaan dan pengolahan dokumen dan informasi elektronik dalam mengembangkan sistem pelayanan publik yang transparan. Adanya Instruksi Presiden (INPRES) tersebut telah mengamanatkan para kepala daerah baik Gubernur maupun Bupati/Walikota untuk melakukan pengembangan E-Government. Jika menurut sejak awal kebijakan tersebut dikeluarkan, maka sudah berjalan 17 tahun komitmen tersebut dikembangkan oleh Pemerintah Indonesia dalam mengembangkan sistem tata kelola pemerintahan berbasis E-Government.

Mengacu pada pemahaman di atas, maka INPRES No 3 tahun 2003 diterjemahkan oleh para pemerintah daerah dalam visi dan misi, sebagai perwujudan layanan pada masyarakat dalam sektor publik. E-Government sebagai landasan pijakan dalam memenuhi kebutuhan sebuah layanan yang lebih meningkatkan kinerja pemerintah serta mereduksi biaya-biaya yang menjadi persoalan selama ini (pemborosan). Adanya itikad untuk mengadopsi teknologi informasi sebagai basis layanan, merupakan indikator pertumbuhan dan peningkatan kinerja dalam mencapai tujuan-tujuan yang telah ditetapkan pada masing-masing daerah. Itikad yang dimaksud tergambar melalui implementasi dalam visi dan misi, perencanaan, dan implementasi, maupun evaluasi teknologi informasi.

Penyusunan strategi TI di pemerintahan dapat melalui 3 jenis strategi yaitu (1) strategi bisnis yang menjadi pedoman untuk menjamin TI agar selaras dalam mendukung pencapaian sasaran organisasi, (2) strategi TI yang menjadi rekomendasi mengenai infrastruktur atau perangkat keras dan pengembangan keahlian Sumber Daya Manusia (SDM) agar TI dapat berjalan sesuai harapan, dan (3) strategi manajemen TI yang menjadi rekomendasi mengenai ITG. Berdasarkan hasil analisis temuan yang diperoleh, maka kebijakan pemerintah pusat sangat berpengaruh terhadap penyusunan tata kelola TI di pemerintah daerah guna mendukung program pemerintah pusat.

\subsection{Penyelarasan Kepemimpinan TI Salatiga}

Ditinjau dari sisi komitmen akan keselarasan teknologi informasi, maka Kota Salatiga dan Kebupaten Bangkayang memiliki komitmen untuk 
menempatkan teknologi informasi sebagai bagian utama yang tergambar dalam visi dan misi kepemimpinan di Kota Salatiga dan Kabupaten Bengkayang. Komitmen Kota Salatiga nampak secara eksplisit dalam misi yang ke-7 (Tujuh) yang ingin meningkatkan Tata Kelola Pemerintahan dengan prinsip-prinsip good governance berbasis partisipasi, transparansi, dan akuntabilitas (Visi Misi Kota Salatiga, 2019).

Dalam memahami penyelarasan teknologi informasi dalam visi kepemimpinan di Kota Salatiga, maka diawali dari perspektif Walikota Salatiga yang telah menjabat selama dua periode. Dari sisi kesadaran, terbesit dalam pandangan beliau bahwa kesadaran untuk mengimplementasikan teknologi informasi dalam periode kepemimpinan yang pertama, namun beliau diperhadapkan dengan kendala untuk memulai hal tersebut. Memang disadari jika Kota Salatiga tidak memulai berpikir untuk mengembangkan teknologi informasi, maka akan berdampak pada ketertinggalan Kota Salatiga dibandingkan dengan Kota/kabupaten lainnya yang sudah menghadirkan penyelarasan tersebut dari aspek perencanaan sampai pada penyediaan anggaran untuk mendukung implementasi tata kelola teknologi informasi. Sejalan dengan hal tersebut, Prasetyo selaku Kepala Dinas Komunikasi dan Informatika (DISKOMINFO) Kota Salatiga menekankan dalam melakukan perannya sebagai pelayanan publik, maka setiap Organisasi Perangkat Daerah (OPD) dituntut untuk melaksanakan pelayanan publik kepada masyarakat secara efisien, efektif, cepat, dan murah. Ia menyadari bahwa hal ini dapat ditempuh dengan menggunakan TI sebagai basis utama pelayanan.

Kota Salatiga dengan slogan SMART yaitu Sejahtera, Mandiri, dan Bermartabat sejak tahun 2016 memiliki tujuan untuk mengembangkan Kota Salatiga sebagai kota yang cerdas (smart city) dengan memanfaatkan kemajuan teknologi informasi untuk meningkatkan kualitas pelayanan publik dari Pemerintah Kota kepada masyarakat kota Salatiga. Arah selanjutnya yang dilakukan Pemerintah Kota Salatiga untuk pengembangan ke arah smart city yaitu Pemerintah Kota Salatiga akan menyiapkan infrastruktur yang bisa mendukung ke arah smart city. Peningkatan pelayanan publik yang bermutu, transparan, akuntabel, mudah, murah, cepat, patut, dan adil kepada seluruh masyarakat, serta pelaksanaan prinsip-prinsip tata kepemerintahan yang baik (good government) guna menunjang kepentingan masyarakat dan dunia usaha, serta mendorong partisipasi dan pemberdayaan masyarakat.

DISKOMINFO Kota Salatiga mulai beroperasi sejak Januari 2017. Namun, di Kota Salatiga saat ini belum memiliki payung hukum yang jelas baik itu berupa peraturan daerah maupun keputusan walikota yang mengatur pengelolaan E-Government untuk menunjang penyelenggaraan pemerintahan di Kota Salatiga. Namun, Kota Salatiga sudah memiliki master plan (blueprint) dalam pengelolaan $E$ Government yang digunakan sebagai dasar untuk menunjang pelaksanaan dan pengembangan $E$ Government.

Terkait penyusunan arsitektur SPBE di Kota Salatiga menjadi tuntutan bagi Dinas Komunikasi dan Informatika pemerintah Kota Salatiga untuk dapat memenuhi apa yang menjadi pendukung dari SPBE. Oleh karena itu, maka semua OPD mendukung penyusunan arsitektur SPBE, karena OPD merupakan unsur dari pemerintah daerah yang membantu atau yang melaksanakan pelayanan publik kepada masyarakat Kota Salatiga, sehingga tuntutan masyarakat adalah bagaimana efektifitas, efisiensi, kecepatan, kemudahan, dan murah untuk merasakan pelayanan publik dengan menggunakan TI. Dengan adanya TI, maka mempermudah pelayanan publik kepada masyarakat, sehingga dengan adanya SPBE yang sudah dibuat sejak tahun 2020 menjadi pedoman bagi DISKOMINFO Kota Salatiga karena setiap OPD yang ada di Kota Salatiga dengan menggunakan TI akan memperlihatkan bagaimana TI berkembang di Kota Salatiga.

SPBE merupakan kunci dari keterpaduan SPBE secara nasional. Penerapan SPBE adalah untuk membangun tata kelola pemerintahan dengan berbasis TI. Sehingga, dengan adanya SPBE berbasis TI dapat menunjang sistem pemerintahan di Kota Salatiga. Selain itu, SPBE juga sebagai alat untuk perencanaan dalam membangun dan menyelaraskan aplikasi di daerah khususnya di Kota Salatiga dan juga pusat. Sehingga tujuan akhir dengan adanya SPBE adalah supaya penyelenggaraan pemerintahan dapat berjalan lebih cepat dan efisien

Selama ini, penerapan TI di Kota Salatiga seperti misalnya di salah satu OPD yaitu Bappeda tidak memiliki aplikasi yang terkait dengan kegiatan kewenangan, kemudian setelah adanya aplikasi yang didukung oleh sarana prasarana TI, maka SDM yang dimiliki dan regulasi harus diatur sehingga semua harus didukung oleh pimpinan lembaga terkait. Kota Salatiga memiliki sumber daya TI, sarana dan prasarana, tetapi jika tidak didukung dengan SDM maka akan mengalami kesulitan. Oleh karena itu, maka semua sumber daya dan pihak yang berkepentingan (stakeholder) perlu diselaraskan oleh semua kewenangan pimpinan di masing-masing OPD.

Terkait pengelolaan sumber daya manusia, di setiap OPD memiliki manajemen masing-masing, tetapi tidak semua memahami mengenai TI. Oleh karena itu, maka mulai dari perencanaan, pengorganisasian, pelaksanaan, sampai dengan monitoring perlu dikelola khusus oleh manajemen TI yang memahami mengenai penerapan SPBE. Dengan adanya SPBE, maka perlu didukung sarana prasarana TI di setiap OPD sehingga dapat diukur bagaimana indeks SPBE di setiap OPD.

Kebijakan DISKOMINFO untuk mengembangkan TI di setiap OPD bertujuan supaya 
setiap OPD dapat menyelesaikan tugas pokok dan fungsi (tupoksi) dengan berbasis elektronik. Melalui sistem yang berbasis digital, maka dapat mempermudah setiap OPD dalam memberikan pelayanan kepada masyarakat Kota Salatiga. Karena dengan tuntutan masyarakat yang tinggi terkait penerapan TI di Kota Salatiga, maka dapat dipenuhi dan dapat disosialisasikan kepada masyarakat.

Setiap OPD memiliki rencana strategis (renstra), tetapi saat ini renstra di setiap OPD ditarik oleh Pemerintah Kota Salatiga dengan nama RPJMD yaitu Rencana Kerja Jangka Menengah Daerah yang memiliki periode 5 tahunan yang dilaksanakan oleh Pemda, dalam hal ini yaitu Wali Kota. Sejak tahun 2017 sampai dengan 2022 akan menjabarkan tentang Visi Misi Wali Kota. Di salah satu misi yaitu nomor 9 adalah terkait dengan penyelenggaraan pemerintahan yang Good governance, maka bagaimana indikator penyelenggaraan pemerintahan yang baik dengan didukung TI.

Di masa pandemi ini, strategi DISKOMINFO sebagai lembaga yang mempersiapkan sarana prasarana TI adalah yang pertama yaitu mempersiapkan SDM untuk dapat menggunakan teknologi video call dan webinar. Strategi kedua yaitu terkait dengan regulasi yang merupakan kebijakan pimpinan terkait kebutuhan selama pandemi. seperti misalnya: sosialisasi, penyebarluasan informasi tentang covid, penanganan covid, dan vaksinasi, baik melalui media sosial dan sebagainya. Oleh karena itu, perlu dipersiapkan sarana prasarana TI, SDM, dan regulasi serta perlunya inovasi dan kreativitas terkait dengan bagaimana DISKOMINFO dapat memberikan pemahaman kepada masyarakat agar peran serta masyarakat terhadap covid juga tinggi.

Terkait dengan penerapan SPBE, Kota Salatiga masih berada dalam tahap penyusunan dokumen mulai tahun 2020. Untuk tahun 2021 ditargetkan masuk ke dalam fase monitoring. Sehingga dengan adanya monitoring terhadap dokumen SPBE dalam pelaksanaannya di setiap OPD masing-masing akan dapat dievaluasi dengan tujuan untuk menyusun dokumen SPBE di tahun berikutnya yaitu pada tahun 2022.

\subsection{Penyelarasan Kepemimpinan TI Bengkayang}

Kabupaten Bengkayang menampakkan komitmen pemimpin daerah melalui misi yang ke-2 (dua) yaitu mewujudkan masyarakat Kabupaten Bengkayang yang cerdas, kreatif dan mampu menguasai ilmu pengetahuan dan teknologi, dan misi yang ke-6 (enam) mewujudkan manajemen pemerintahan yang profesional dan bersih dengan prinsip melayani (Visi Misi Pemerintah Kabupaten Bengkayang, 2019).

Sekretaris Daerah Kabupaten Bengkayang, memiliki kesadaran dan komitmen untuk melakukan penyelenggaraan pemerintahan berbasis TI. Lebih jauh, Sekretaris Daerah Kabupaten Bengkayang menyatakan bahwa dalam semua basis penyelenggaraan pemerintahan, baik dalam bidang kepegawaian, keuangan, pengawasan, perencanaan, perijinan, perdagangan, UKM, Perhubungan, sampai pada kependudukan hendaknya sudah mengadopsi TI sebagai basis pelayanan pada masyarakat. Oleh karena itu, dalam pengembangan teknologi informasi di Kabupaten Bengkayang, diawali dengan penyusunan Rencana Induk Informasi dan Teknologi pada tahun 2013, dan dilanjutkan dengan pembangunan Standard Operating Procedure (SOP) TI sampai saat ini menjadi perhatian utama.

Melalui tata kelola, akan diperoleh informasi yang cepat dan valid, informasi yang diperoleh akan transparan dan dari sisi pengendalian, dapat dilihat kejadian-kejadian daripada administrasi yang terkontrol dan diperkuat oleh kehadiran SOP. Menurut Sekretaris Daerah Kabupaten Bengkayang, tata kelola penyelenggaraan pemerintahan merupakan salah satu bentuk reformasi birokrasi yang mendasarkan pada sistem good governance.

Pengembangan tata kelola teknologi informasi membutuhkan kesamaan visi dan misi. Menurut Sekretaris Daerah Kabupaten Bengkayang, penerapan dan pengembangan tata kelola TI dapat berjalan dengan baik apabila setiap unsur pemerintahan baik KOMINFO maupun perangkat daerah lainnya perlu duduk bersama dan membangun kesatuan pemahaman akan pentingnya TI dan bagaimana menempatkan KOMINFO sebagai unit pengendali dan pengelola sistem teknologi informasi di Bengkayang. Adanya komitmen satu tujuan melalui satu data, perlu didorong melalui kolaborasi antar admin setiap OPD dengan KOMINFO, sehingga berada pada satu visi satu pemahaman. Contohnya setelah APBD disahkan maka langsung dapat terbaca pada setiap OPD dan publik sebagai keterbukaan informasi publik.

Sekretaris Daerah Kabupaten Bengkayang memandang bahwa pemanfaatan TI sangat penting dari sisi administrasi guna membantu dalam melakukan pelacakan, pengendalian semua program yang dijalankan. Dari sisi pelaksanaan, maka hal ini sangat membantu pengawasan terhadap programprogram yang dilakukan. Mengacu pada progress yang dapat disampaikan dalam sistem TI, maka hal ini dapat menjadi laporan awal, yang nantinya diikuti dengan pengecekan kondisi di lapangan. Misalnya dalam bidang pembangunan jembatan, tidak perlu ke lapangan terlebih dahulu, tetapi dapat menggunakan TI untuk mengecek lokasi-lokasi yang ada di wilayah terkait sejauh mana proses pengerjaan jembatan dilakukan. TI pada bidang pendidikan digunakan untuk memudahkan bagaimana hubungan antara guru dengan murid supaya mereka saling bertemu di satu media seperti itu.

Sebaliknya dalam perencanaan anggaran, yang akan lebih mengarahkan ke paperless (peminimalan penggunaan kertas). Dalam hal administrasi, kertas menjadi beban karena pemanfaatan yang besar. Pemanfaatan kertas juga berimplikasi pada 
ketersediaan ruang penyimpanan berkala besar. Sedangkan pada permasalahan pajak, melalui TI maka dapat dilakukan monitoring pelaksanaan pajak.

Sekretaris Daerah Kabupaten Bengkayang memandang bahwa Kabupaten Bengkayang perlu secara cepat melakukan adopsi dan penyesuaian sistem penyelenggaraan pemerintah berbasis teknologi informasi. Perlu dilakukan antisipasi perkembangan TI. Hal inilah yang mendasari mengapa Kabupaten Bengkayang sejak awal melakukan adopsi TI melalui penyusunan Rencana Strategis Teknologi Informasi dan menyelenggarakan sistem pemerintahan berbasis TI. Kehadiran TI saat ini sudah dipandang sebagai kebutuhan yang wajib dipenuhi, dan bukan merupakan paksaan. Tujuannya guna mengejar ketertinggalan Kabupaten Bengkayang dibandingkan dengan daerah-daerah lainnya di Indonesia.

Kehadiran TI sangat penting dalam mendukung pencapaian kinerja birokrasi pemerintah. Menurut Sekretaris Daerah Kabupaten Bengkayang, dengan menerapkan teknologi informasi maka dapat: 1) mengukur capaian kinerja untuk melakukan prediksi atau peramalan berdasarkan data dan informasi yang disediakan melalui TI; 2) Memanfaatkan teknologi informasi maka akan mendukung implementasi transparansi dan tata laksana aturan tertentu. Melalui teknologi informasi, dapat mengurangi resiko yang ditimbulkan serta kecurangan-kecurangan dapat dideteksi dini, misalnya korupsi. Teknologi informasi dibangun sedemikian rupa, sehingga dapat mencegah individu atau kelompok untuk mengambil kesempatan pada titik tertentu, baik dalam perencanaan, pelaksanaan, monitoring. dan laporan atau pertanggungjawaban. Sehingga daerah dapat terhindarkan dari urusan pemerintah yang akan merugikan.

Lebih jauh, Kepala Dinas Komunikasi dan Informatika Kabupaten Bengkayang memandang bahwa rendahnya adopsi TI dalam sistem pemerintahan di Kabupaten Bengkayang menjadi masalah yang harus diselesaikan secepatnya. Misalnya dalam konteks penyelenggaraan webinar, DISKOMINFO mencoba mengukur kualitas internet melalui BTS di setiap kecamatan dan desa, ditemukan bahwa kualitas internet tidak sepenuhnya optimal dan menjadi masalah dalam penyelenggaraan webinar tersebut. Saat ini Kabupaten Bengkayang hanya memiliki 114 menara BTS dan 21 menara dari Kementerian KOMINFO, sehingga untuk memenuhi kebutuhan infrastruktur masih sangat kurang, yang dibuktikan dengan sinyal internet yang sangat lemah.

Menurut Kepala Dinas Komunikasi dan Informatika Kabupaten Bengkayang, Pemerintah mengambil kebijakan pada tahun 2013 dengan prioritas pada bidang pendidikan melalui penyediaan sarana internet untuk sekolah terutama pada daerah perbatasan dengan Negara Malaysia. Demikian juga dengan puskesmas untuk bidang kesehatan. Prioritas pada bidang pendidikan dan kesehatan, ternyata memberikan manfaat yang besar, terutama dalam masa pandemi covid-19, yang mana sangat mendukung untuk pembelajaran daring/online maupun juga dalam pelayanan kesehatan. Harapannya dengan dukungan sinyal internet yang baik, maka akan mendukung setiap aktivitas yang ada.

Pemanfaatan TI dalam mendukung urusan pemerintah bisa menyebabkan efisiensi pengeluaran $20 \%-25 \%$ dari total pengeluaran pemerintah menurut Kepala Dinas Komunikasi dan Informatika Kabupaten Bengkayang. Misalnya dalam konteks pendapatan aset, keberadaan sistem perpajakan dapat mengurangi sumber daya untuk melakukan pungutan yang selama ini dilakukan manual. Adanya pendapatan aset berbasis TI maka pembayaran pajak pendapatan dapat dilakukan secara digital, sehingga pemerintah dapat mengukur potensi pendapatan harian maupun bulanan dari sektor tersebut. Demikian juga, dalam hal retribusi daerah, sehingga dalam perencanaan kas daerah semua menjadi terkontrol.

Kabupaten Bengkayang pada hakekatnya telah didukung oleh regulasi yang baik, namun komitmen terhadap ketersediaan anggaran dan pendanaan masih kurang. Hal ini nampak dalam pernyataan Kepala Dinas Komunikasi dan Informatika Kabupaten Bengkayang yang memandang bahwa dari sisi regulasi sudah siap namun pendanaan belum mengarah untuk mendukung regulasi, karena jika pemerintah menginginkan untuk mengembangkan sistem satu data, pemerintah belum memiliki infrastruktur yang baik serta belum dimiliki sistem jaringan induk sebagai basis pengembangan infrastruktur.

Ketersediaan anggaran menjadi kendala besar bagi Kabupaten Bengkayang, terutama dalam mewujudkan tata kelola penyelenggaraan urusan pemerintahan berbasis TI, meskipun dari sisi kebijakan, sudah direspon. Namun persoalannya terletak pada bagaimana kebijakan tersebut dijabarkan dengan sarana yang terbatas. Kepala DISKOMINFO Kabupaten Bengkayang mengungkapkan bahwa selama ini kebijakan yang ada tidak didukung dengan ketersediaan anggaran. Hal ini disebabkan karena dalam mengembangkan infrastruktur, dibutuhkan investasi yang besar melalui ketersediaan dan dukungan anggaran oleh pemerintah.

Ditinjau dari narasumber penelitian ini diperoleh bahwa ketersediaan SDM dalam mendukung pengembangan tata kelola berbasis TI sangatlah penting. Kepala DISKOMINFO Kabupaten Bengkayang memandang bahwa kolaborasi antara Universitas Kristen Satya Wacana dan Pemerintah Kabupaten Bengkayang sangat membantu dalam pengembangan SDM. Menurut Kepala Dinas Komunikasi dan Informatika Kabupaten Bengkayang, pada saat ini Kabupaten Bengkayang memiliki 21 orang sarjana lulusan TI. SDM tersebut 
tersebar pada OPD-OPD Kabupaten Bengkayang. Narasumber mengakui bahwa ketersediaan SDM yang ada saat ini masih sangat kurang. Berbagai upaya dilakukan untuk memenuhi kebutuhan dan ketersediaan sumberdaya tersebut, salah satunya dengan menyekolahkan mereka ke perguruan tinggi.

Narasumber memandang dibutuhkannya komitmen melalui kehadiran dan implementasi kebijakan dan dukungan ketersediaan anggaran dalam mewujudkan implementasi tata kelola teknologi informasi di Kabupaten Bengkayang. Dukungan selama ini diwujudkan melalui kehadiran rencana strategis dan standard operating procedure tata kelola teknologi informasi. Komitmen ini juga nampak melalui pemisahan DISKOMINFO sebagai dinas otonom yang khusus memiliki tupoksi bidang teknologi informasi.

Komitmen kepemimpinan tersebut akan selaras pada konteks pandemi covid-19 pada saat ini. Para narasumber memandang bahwa pandemi yang ada telah memaksa pemerintah untuk melakukan aktivitas berbasis teknologi informasi. Perubahan perilaku nampak melalui sistem komunikasi dan administrasi yang selama ini berbasis fisik dan manual, berubah melalui pemanfaatan teknologi informasi.

\subsection{Tata Kelola Teknologi Informasi Sebagai Basis Reformasi Birokrasi}

Proses perencanaan dan implementasi ITG sangat bergantung pada adanya kesadaran dan komitmen pada pemangku kepentingan dalam sektor publik yang diimplementasikan dalam tujuan dan arah pengembangan daerah tersebut. Jika seorang pemimpin tidak memiliki kesadaran dan komitmen untuk mengimplementasikan serta mengontrol implementasi teknologi informasi, maka hal tersebut hanya bersifat kesia-siaan. Visi dan misi pemimpin menjadi kunci dalam kesuksesan implementasi $E$ Government (Neil dkk., 2018). Komitmen nampak melalui visi kepemimpinan yang disampaikan dalam pernyataan tujuan dalam periode kepemimpinan yang ada.

Kota Salatiga dan Kabupaten Bengkayang memiliki komitmen yang kuat dalam menempatkan tata kelola teknologi informasi sebagai basis pelayanan birokrasi, yang tergambar dalam visi dan misi. Komitmen tersebut nampak jelas dalam menghadirkan sistem pemerintahan yang memiliki good governance terutama dalam mengembangkan basis layanan yang bersifat partisipatif, transparan, dan akuntabel. Adanya komitmen menjadi pondasi utama dalam mengembangkan sistem pelayanan pada masyarakat. Mengacu pada pemahamanan tersebut, maka yang menjadi tantangan dalam implementasi teknologi informasi di Kota Salatiga dan Kabupaten Bengkayang adalah kemampuan pemimpinnya dalam menerjemahkan visi dan misi yang menempatkan teknologi informasi sebagai basis pengelolaan tata kelola yang baik (good governance).
Komitmen untuk menggunakan TI sebagai basis penyelenggaraan urusan birokrasi nampak jelas dalam pernyataan visi dan misi kedua daerah tersebut. Adanya komitmen menjadi perhatian penting, mengingat pemimpin atau kepala daerah merupakan pihak sebagai penentu arah pembangunan daerah. Kepala daerah merupakan faktor penting yang bertindak sebagai pengambil keputusan (decision maker) dalam perwujudan implementasi tersebut. Faktor keberhasilan dan efektivitas implementasi tata kelola sangat bergantung pada kepemimpinan yang ada. Selain itu, faktor pemimpin/pejabat memiliki peranan penting dalam implementasi E-Government sebagai basis tata kelola teknologi informasi.

Dalam mencapai keberhasilan implementasi teknologi informasi, dibutuhkan dorongan dan dukungan kepemimpinan berbasis teknologi informasi yang kuat. Oleh karena itu, dalam mengembangkan good governance di Kota Salatiga dan Kabupaten Bengkayang memandang bahwa adanya komitmen yang sudah dinyatakan dalam visi dan misi, maka dibutuhkan implementasi teknologi informasi dalam setiap aspek dan perilaku aktivitas yang ada dibawahnya. Adanya kesadaran dari para pemimpin di kedua daerah tersebut, telah menjadi dorongan untuk mulai menata diri dari system berbasis IT governance. Kota Salatiga dan Kabupaten Bengkayang membutuhkan kesatuan pemahaman baik dari sisi kepemimpinan, struktur organisasi, dan proses yang terdapat di dalamnya guna mendukung pencapaian tujuan berbasis teknologi informasi.

Kinerja tata kelola TI yang dikembangkan di Kota Salatiga dan Kabupaten Bengkayang, membutuhkan dukungan dari pemimpin selaku pejabat yang memiliki kewenangan dalam melakukan mengkonsolidasi, standarisasi, maupun mengelola infrastruktur TI dan aplikasi sistem informasi guna mengoptimasi biaya dan aliran informasi pada organisasi publik. Hal ini terlihat dalam komitmen dan itikad pemimpin di kedua daerah tersebut dalam mendorong implementasi teknologi informasi.

Kesadaran akan pentingnya implementasi TI nampak dalam komitmen para pemimpin di Kota Salatiga melalui kehadiran roadmap reformasi birokrasi Pemerintah Kota Salatiga tahun 2020-2022 dalam maksud untuk keterbukaan informasi publik melalui ketersediaan informasi publik, pengembangan E-Government dan Smart City dalam mewujudkan tata kelola pemerintahan. Tujuannya adalah penyederhanaan struktur dan kelembagaan birokrasi serta transformasi digital, yaitu teknologi dimanfaatkan untuk peningkatan pelayanan publik pada masyarakat. Demikian juga Kabupaten Bengkayang, itikad tersebut Nampak melalui Peraturan Bupati Bengkayang Nomor 19 Tahun 2020 Tentang Tata Kelola Penyelenggaraan Sistem Pemerintahan Berbasis Elektronik (E-Government) di Kabupaten Bengkayang. Guna memperkuat hal tersebut, maka Kabupaten Bengkayang menerbitkan Peraturan Bupati Nomor 53 tentang satu data 
Indonesia, sebagai perwujudan implementasi tata kelola teknologi informasi. Mengacu pada pemahaman tersebut, maka keberadaan aturan di kedua daerah tersebut menunjukkan adanya komitmen melalui produk aturan/hukum yang mendorong terjadinya penyelarasan antara visi dan implementasi praktis.

Berdasarkan sisi kelembagaan, Kota Salatiga maupun Kabupaten Bengkayang telah membentuk DISKOMINFO sebagai unit yang diberikan kewenangan khusus dalam bidang teknologi informasi dan komunikasi. Tingginya komitmen terhadap pengembangan tata kelola yang baik, telah mendorong kedua daerah tersebut untuk melalui pemisahan Dinas Komunikasi dan Informatika dari Dinas Perhubungan, komunikasi dan Informatika. Langkah berikutnya adalah melakukan penataan dan konsolidasi sistem pengelolaan teknologi informasi, serta secara bertahap melakukan penyiapan anggaran pengembangan teknologi informasi. Kota Salatiga dan Kabupaten Bengkayang menempatkan Dinas Komunikasi dan Informatika dalam menjalankan fungsi sebagai dewan pengawas TI yang bertanggung jawab dalam pengembangan dan implementasi TI. Memang ditemukan permasalahan seperti rendahnya pemahaman DISKOMINFO dalam menjalankan peran sebagai dewan pengawas TI di kedua daerah tersebut. Hal ini juga didukung dengan rendahnya pemahaman OPD terkait peran dan tugas DISKOMINFO, yang berdampak pada koordinasi dan komunikasi antar OPD dengan DISKOMINFO dalam melakukan perencanaan dan implementasi TI. Kondisi tersebut menyebabkan tumpang tindih kewenangan dan tanggung jawab dalam pengembangan $\mathrm{TI}$.

Dalam rangka menghindari dampak negatif yang ditimbulkan oleh masalah di atas, maka para pejabat di Kota Salatiga maupun Kabupaten Bengkayang perlu mengembangkan komunikasi antar OPD, serta dibangun kebijakan yang dapat menggambarkan tugas, fungsi dan kewenangannya, sampai dengan kinerja keuangan/peranggaran. Ketersediaan kebijakan dan dibangunnya kultur komunikasi yang baik akan membawa Kota Salatiga maupun Kabupaten Bengkayang dalam mengembangkan tata kelola pelayanan publik yang kuat, terutama dalam mencapai kepuasan masyarakat sebagai konsumen utama.

Kota Salatiga dan Kabupaten Bengkayang memiliki itikad dan keinginan yang besar dalam mengembangkan tata layanan birokrasi pada masyarakat dengan memanfaatkan teknologi informasi sebagai bagian dari aktivitas pemerintahan. Berbagai kebijakan didorong sebagai bagian dari keterbukaan informasi publik, seperti yang nampak dalam roadmap reformasi birokrasi Kota Salatiga dan tata kelola penyelenggaraan pemerintah berbasis $E$ Government. Tingginya komitmen nampak dalam langkah pemerintah Kota Salatiga menyediakan website keterbukaan informasi publik (https://ppid.salatiga.go.id). Demikian juga Kabupaten Bengkayang yang dikembangkan melalui https://bengkayangkabppid.kpu.go.id/profil_ppid.

Hal ini juga diperkuat dengan keinginan untuk mengembangkan aplikasi-aplikasi teknologi informasi pendukung sebagai pendukung implementasi tata kelola dalam pelayanan publik.

Pengembangan tata kelola pemerintah yang baik (good governance), membutuhkan teknologi informasi sebagai bagian dari perencanaan pengembangan layanan publik yang efisien dan efektif. Kota Salatiga pada hakikatnya sudah memiliki roadmap reformasi birokrasi yang berorientasi pengembangan E-Government dan Smart City, namun hal ini tidak diikuti dengan ketersediaan payung hukum kebijakan maupun aturan sebagai basis implementasi roadmap tersebut.

Kabupaten Bengkayang sejak tahun 2013 telah mengembangkan rencana strategis informasi dan teknologi, yang diikuti dengan pengembangan SOP berbasis TI. lebih daripada itu, pada tahun 2020, dikeluarkan Peraturan Bupati Nomor 19 tentang implementasi E-Government dan Peraturan Bupati No. 53 tentang Satu Data Indonesia. Kesadaran tersebut telah juga disampaikan oleh para narasumber yang ingin mendapatkan dan mengeluarkan informasi dengan cepat yang transparan dan dapat dipertanggungjawabkan. Meskipun temuan lapangan memperlihatkan bahwa belum sepenuhnya ada keseriusan dalam mengembangkan tata kelola pemerintahan berbasis TI, namun terlihat ada kesadaran Pemerintah Kota Salatiga maupun Kabupaten Bengkayang untuk mengimplementasi tata kelola TI sebagai basis layanan publik. Data lapangan menunjukkan keselarasan dalam melihat pentingnya tata kelola teknologi informasi dalam perencanaan, seperti yang telah disampaikan oleh Terblanche.

Melalui perencanaan Teknologi Informasi, diharapkan dapat mendukung peningkatan kinerja pemerintahan. Melalui ketersediaan informasi para narasumber di Kota Salatiga maupun Kabupaten Bengkayang berharap dapat mengambil keputusan yang tepat serta masyarakat dapat memperoleh informasi secara transparan. Para pemimpin di kedua daerah menginginkan agar pemanfaatan TI dapat membantu dalam meminimalkan praktek-praktek yang berpotensi menjadi permasalahan hukum. Harapan nampak dalam pernyataan para narasumber dari Kabupaten Bengkayang yang menginginkan teknologi informasi digunakan sebagai sarana dalam meminimalkan perilaku kecurangan yang dapat mengarah pada tindakan korupsi. Melalui tata kelola pemerintah yang baik, para pemimpin di Kabupaten Bengkayang dapat mengantisipasi perilaku-perilaku kecurangan melalui pemanfaatan teknologi informasi. Hal tersebut nampak melalui keinginan untuk membangun sistem penyelenggaraan pemerintahan sebagai bentuk reformasi birokrasi berbasis good governance. 
Guna melakukan penyelarasan visi tata kelola pemerintahan pada pemimpin maka dibutuhkan dukungan anggaran, sumber daya manusia, dan infrastruktur. Penataan dari sisi struktur, proses, dan sistem relasi diperlukan sebagai bagian dari tata kelola TI. Mengacu pada pemahaman tersebut, Kota Salatiga dan Kabupaten Bengkayang memberikan perhatian terhadap hal tersebut.

Dalam rangka mencapai tata kelola pemerintahan, dibutuhkan dukungan dan ketersediaan anggaran dalam mencapai tujuan reformasi birokrasi. Temuan lapangan menunjukkan bahwa dukungan anggaran masih mendapat perhatian/porsi yang rendah. Meskipun dari sisi komitmen sudah baik, namun tidak ditindaklanjuti dengan alokasi anggaran dalam mengembangkan tata kelola pemerintah. Para narasumber mengeluhkan perhatian Walikota maupun Bupati dalam prioritas pengembangan tata kelola pemerintahan berbasis teknologi informasi. Masalah utama yang dikeluhkan adalah persoalan anggaran untuk memaksimalkan nilai sumberdaya ITG. Selain itu, dalam pengembangkan ITG juga dihadapkan dengan sistem anggaran yang kaku pada sektor publik. Hal ini juga ditemukan dalam pandangan para narasumber dari Kota Salatiga dan Kabupaten Bengkayang yang memandang bahwa dalam implementasikan tata kelola TI pada sektor publik perlu menyelaraskan antara kinerja organisasi dengan kinerja TI (Tonelli, et al., 2017).

Ditinjau dari sisi penyediaan infrastruktur, Kota Salatiga memiliki kesiapan infrastruktur yang lebih baik ketimbang Kabupaten Bengkayang. Posisi Kota Salatiga yang berada di Pulau Jawa memungkin dapat memperoleh perhatian tinggi dari pemerintah pusat dalam membangun infrastruktur. Sedangkan, Kabupaten Bengkayang berada di wilayah perbatasan yang mana dukungan infrastruktur masih sangat rendah. Kondisi Kabupaten Bengkayang nampak dalam penuturan para narasumber yang menyatakan tentang kualitas internet yang rendah dan minimnya infrastruktur. Perhatian dan alokasi anggaran untuk pengembangan infrastruktur perlu menjadi perhatian dalam mencapai reformasi birokrasi melalui pengembangan tata kelola pemerintahan berbasis teknologi informasi.

Salah satu faktor penting dalam pengembangan tata kelola pemerintahan berbasis teknologi informasi, adalah ketersediaan sumber daya manusia. Baik Kota Salatiga maupun Kabupaten Bengkayang memiliki permasalahan utama tentang sumber daya manusia. Pada umumnya sumber daya manusia yang ada belum dapat memenuhi kebutuhan sumber daya dalam pengembangan teknologi informasi. Hal ini tampak dalam penuturan narasumber baik dari Kota Salatiga maupun Kabupaten Bengkayang. Mereka juga diperhadapkan dengan persoalan kompetensi yang rendah dari sumberdaya tersebut. Kondisi tersebut sudah diingatkan oleh Benaroch \& Chernobai tentang persoalan kompetensi para IT
Board serta rendahnya keterampilan interpersonal maupun kepemimpinan oleh Thite. Dampak yang ditimbulkan sampai pada transfer pengetahuan, terutama dalam diseminasi pengetahuan dalam pemerintahan.

Kota Salatiga maupun Kabupaten Bengkayang memilih beberapa langkah sebagai strategi implementasi pengembangan tata kelola pemerintahan berbasis reformasi birokrasi. Baik Kota Salatiga dan Kabupaten Bengkayang melakukan penataan kelembagaan melalui kehadiran DISKOMINFO. Secara spesifik, Kota Salatiga melakukan pengembangan aplikasi dan penataan regulasi, serta penataan kewenangan berbasis pemimpin OPD. Kabupaten Bengkayang lebih melihat pada penyediaan regulasi dan penataan tata kelola melalui SOP berbasis TI, dan penyiapan SDM melalui pengiriman mahasiswa ke beberapa perguruan tinggi. Harapannya melalui ketersediaan sumber daya manusia, maka dapat mengisi kekosongan SDM di masing-masing OPD di lingkungan Pemerintah Kabupaten Bengkayang.

Implementasi E-Government di Kota Salatiga maupun di Kabupaten Bengkayang tidak hanya sekedar melakukan pengadaan perangkat komputer di kantor OPD tersebut, dikarenakan E-Governmant memiliki banyak konsekuensi bagi pemerintah daerah yang akan mengharuskan mereka bekerja secara profesional. Implementasi E-Government di kantor-kantor tersebut juga perlu didukung oleh para pegawai yang mampu memahami mengenai TI karena perubahan dan perkembangan TI berubah secara cepat. Selain itu implementasi E-Government membutuhkan perubahan di dalam organisasi dan dukungan ketrampilan terhadap perkembangan TI yang baru. Implementasi E-Government perlu dikombinasikan dengan perubahan organisasi yang baru dalam rangka memperbaiki dan meningkatkan pelayanan publik dalam mendukung kebijakan publik yang telah ditetapkan oleh pemerintah daerah.

Berdasarkan analisis yang dilakukan terhadap kedua pemimpin daerah di Kota Salatiga dan Kabupaten Bengkayang, maka ditemukan faktorfaktor yang memiliki peran penting dalam implementasi tata kelola TI di dalam pemerintahan daerah. Faktor-faktor tersebut antara lain yaitu: 1) Adanya komitmen Walikota Salatiga dan Bupati Bengkayang yang terjabar melalui visi dan misi di daerahnya untuk mengembangkan tata kelola pemerintah berbasis good governance; 2) Kemampuan pemimpin daerah di Kota Salatiga dan Kabupaten Bengkayang dalam menjabarkan visi dan misi tersebut guna menghasilkan tata kelola pemerintah yang baik; 3) Ketersediaan regulasi, aturan, dan kebijakan yang mendukung implementasi tata kelola TI; 4) Dorongan dan dukungan dalam implementasi tata kelola teknologi informasi di Kota Salatiga dan Kabupaten Bengkayang; 5) Kemampuan pemimpin daerah dalam melakukan konsolidasi, standarisasi, maupun pengelolaan infrastruktur TI 
dan aplikasi sistem informasi yang diterapkan di setiap OPD; 6) Penataan kelembagaan melalui kehadiran unit khusus yang berwenang dalam bidang tata kelola TI; 7) Dukungan dan alokasi anggaran yang difokuskan pada implementasi TI; 8) Ketersediaan infrastruktur TI; 9) Alokasi dan penyiapan SDM dalam bidang TI untuk dapat mengelola dan mengoperasikan setiap aplikasi sistem informasi yang ada; serta 10) Kemampuan mengembangkan strategi implementasi guna mendorong terwujudnya tata kelola TI dalam mengembangkan tata kelola pemerintahan yang berbasis TI.

Visi Kepemimpinan menjadi landasan dalam pengembangan tata kelola teknologi informasi pada sector publik. Mengacu pada pemahaman tersebut, tidak nya komitmen melalui keberadaan visi kepemimpinan, namun hal ini perlu disertai dengan strategi dan keinginan untuk menurunkan visi tersebut dalam operasionalisasi tata kelola TI.

Sebagai tindak lanjut untuk mengimplementasikan strategi TI berdasarkan visi kepemimpinan pemerintah daerah, maka diperlukan rumusan strategi untuk pengelolaan TI, seperti dokumen rencana strategi TI dan dokumen master plan TI, serta pembaruan berbagai SI yang digunakan pada organisasi yang membutuhkan dukungan layanan $\mathrm{TI}$.

\section{KESIMPULAN}

Kehadiran tata kelola teknologi informasi sangatlah penting guna mengembangkan reformasi birokrasi dalam mencapai sistem pemerintahan yang baik di Kota Salatiga dan Kabupaten Bengkayang. Untuk mencapai tujuan tersebut, maka dibutuhkan visi kepemimpinan yang kuat dalam menempatkan teknologi informasi sebagai bagian utama untuk mencapai visi tata pemerintahan pada sektor publik. Mengacu pada pemahaman tersebut, penelitian ini menemukan faktor-faktor yang memiliki peran dalam implementasi tata kelola TI. Faktor-faktor tersebut yaitu: 1) Adanya komitmen Walikota Salatiga dan Bupati Bengkayang yang terjabar melalui visi dan misi di daerahnya untuk mengembangkan tata kelola pemerintah berbasis good governance; 2) Kemampuan pemimpin daerah di Kota Salatiga dan Kabupaten Bengkayang dalam menjabarkan visi dan misi tersebut guna menghasilkan tata kelola pemerintah yang baik; 3) Ketersediaan regulasi, aturan, dan kebijakan yang mendukung implementasi tata kelola TI; 4) Dorongan dan dukungan dalam implementasi tata kelola teknologi informasi di Kota Salatiga dan Kabupaten Bengkayang; 5) Kemampuan pemimpin daerah dalam melakukan konsolidasi, standarisasi, maupun pengelolaan infrastruktur TI dan aplikasi sistem informasi yang diterapkan di setiap OPD; 6) Penataan kelembagaan melalui kehadiran unit khusus yang berwenang dalam bidang tata kelola TI; 7) Dukungan dan alokasi anggaran yang difokuskan pada implementasi TI; 8)
Ketersediaan infrastruktur TI; 9) Alokasi dan penyiapan SDM dalam bidang TI untuk dapat mengelola dan mengoperasikan setiap aplikasi sistem informasi yang ada; serta 10) Kemampuan mengembangkan strategi implementasi guna mendorong terwujudnya tata kelola TI dalam mengembangkan tata kelola pemerintahan yang berbasis TI.

Kehadiran visi kepemimpinan dalam mengembangkan tata kelola pemerintahan menjadi faktor kunci guna mengembangkan reformasi birokrasi menuju sistem pemerintahan yang berorientasi layanan pada masyarakat. Hasil penelitian menunjukkan bahwa meskipun Kota Salatiga dan Kabupaten Bengkayang masih lemah dalam implementasi dan dukungan anggaran, namun kesadaran untuk menempatkan tata kelola TI sudah memiliki visi penempatan TI sebagai basis penyelenggaraan birokrasi.

\section{DAFTAR PUSTAKA}

ALFORD, J. AND GREVE, C. 2017. "Strategy in the Public and Private Sectors: Similarities, Differences and Changes". Adm. Sci., 7, 35. https://doi.org/10.3390/admsci7040035.

ALI, A. AND NISAR, A. 2016. "Conceptualizing IT Governance Principles at Strategic Projects Level'. International Journal of Computer Science and Information Security. 14. 898-907.

ALREEMY, Z., CHANG, V., WALTERS, ROBERT AND WILLS, G. 2016. "Critical success factors (CSFS) for information technology governance (ITG)". International Journal of Information Management, 36 (6), part A, 907916.

http://dx.doi.org/10.1016/j.ijinfomgt.2016.05.0 17.

AMIRI, N. A., RAHIM, R. E. A., AHMED, G. 2020. "Leadership Styles and Organizational Knowledge Management Activities: A Systematic Review". International Journal of Business. 22 (3).

BELHAJ, A. AND ZAHI, J. 2019. "Implementation of IT Governance in A Regional Public Organization". Revue Economie, Gestion et Société. ffhal-02270856f.

BENAROCH, M. AND CHERNOBAI, A. 2017. “Operational IT Failures, IT Value Destruction, and Board-Level IT governance Changes" MIS $Q$., vol. 41, no. 3 .

BUDIRAHARJO, R. 2017. "Penerapan Weill-Ross Model dalam Tata Kelola Teknologi Informasi di Perguruan Tinggi". TEKNOSI. 03 (01).

CHONG, J. L. L. AND DUONG, L. N. K. 2017. "Understanding IT Governance Effectiveness in Asia: an Event Study" Pacific Asia J. Assoc. Inf. Syst., vol. 9, no. 1, pp. 29-54.

EL-EBIARY ET AL. 2020. "Models of Leadership in Information Technology Projects". Solid State Technology. 
GILBERT, R. 2018. "Cultural Studies: an Introduction" Cultural Studies.

ILMUDEEN, A. 2021. "The impact of managing IT on business-IT alignment and firm performance: an empirical study". foresight. ahead-of-print. https://dx.doi.org/10.1108/FS11-2020-0116.

LAITA, A. AND BELAISSAOUI, M. 2017. "Information Technology Governance in Public Sector Organizations". Advances in Intelligent Systems and Computing. https://dx.doi.org/10.1007/978-3-319-46568534.

LARSEN, A., VOLDEN, G., AND ANDERSEN, B. 2021. "Project Governance in State-Owned Enterprises: The Case of Major Public Projects' Governance Arrangements and Quality Assurance Schemes". Administrative Sciences. https://dx.doi.org/11.66.10.3390/admsci1 10300 66.

LAUREANI, A. \& ANTONY, J. 2016. "Leadership - a critical success factor for the effective implementation of Lean Six Sigma". Total Quality Management \& Business Excellence. 29.

$1-22$. https:///dx.doi.org/10.1080/14783363.2016.121 1480.

MILES, M. AND HUBERMAN, A. M. 2014. "An Expanded Sourcebook: Qualitative Data Analysis". New Delhi: SAGE Publisher India Pvt.ltd.

NEIL, S. R., TANAAMAH, A. R. DAN WIJAYA, A. F. 2018. "Pemodelan Proses dan Dampak Transfer, Adopsi, dan Implementasi Teknologi Informasi di Sektor Publik: Sebuah Perspektif Kelembagaan", Laporan Penelitian Hibah Fundamental UKSW.

NOR, R., GANI, A., SALEH, C. AND AMIN, F. 2021. "Organizational commitment and professionalism to determine public satisfaction through good governance, public service quality, and public empowerment". International Review on Public and Nonprofit Marketing. https://dx.doi.org/10.1007/s12208021-00297-0.

PANDA, S. 2021. "Strategic IT-business alignment capability and organizational performance: roles of organizational agility and environmental factors". Journal of Asia Business Studies. ahead-of-print. https://dx.doi.org/10.1108/JABS-09-20200371.

REN, MIN. 2019 "Why technology adoption succeeds or fails: an exploration from the perspective of intra-organizational legitimacy". J. Chin. Sociol. 6, 21. https://dx.doi.org/10.1186/s40711-019-0109-x.

TONELLI, A., BERMEJO, D.S., PAULO, PÂMELA, S., ZUPPO, L. AND ZAMBALDE, A. 2017. "IT governance in the public sector: a conceptual model'. Information Systems Frontiers. 19. https://dx.doi.org/10.1007/s10796-015-9614-x.

WIEDENHOFT, G. C., LUCIANO, E. M., MAGNAGNAGNO, O. A. 2017. "Information Technology Governance in Public Organizations: Identifying Mechanisms That Meet its Goals While Respecting Principles". J. Inf. Syst. Technol. Manag. 14 (1). https://dx.doi.org/10.4301/S180717752017000100004.

WU, S.P., STRAUB, D. W., AND LIANG, T. P. 2015. "How Information Technology Governance Mechanisms and Strategic Alignment Influence Organizational Performance: Insights from a M Atched S Urvey of Business and IT Managers 1" MIS Q., vol. 39, no. 2, pp. 497-518.

VISI MISI PEMERINTAH KABUPATEN BENGKAYANG. 2019. $<$ https://bengkayangkab.go.id/tentangkami/visi-misi/> [Diakses 1 September 2019].

VISI MISI PEMERINTAH KOTA SALATIGA. 2019. $<$ http://salatigakota.go.id/PemerintahanVisiMis i.php $>$ [Diakses 1 September 2019]. 